\title{
Design approach for squeezing ground
}

\author{
RP Varden MineGeoTech, Australia \\ MJ Woods BHP Billiton, Australia
}

\begin{abstract}
Many mines experience squeezing ground conditions due to orebodies located in weak rock masses. Often, the conditions leading to squeezing ground are not recognised or underestimated at the feasibility stage, leading to significant difficulties in mining the deposit, high costs and lost resources. There are a number of processes to determine the potential existence and degree of squeezing ground. Feasibility study to determine the rock mass behaviour will significantly reduce the risks associated with mining such deposits. In many cases, it is not possible to prevent squeezing occurring; however, good planning at the feasibility stage can provide the means to control the ground to allow economical extraction.

The aim of this paper is to present an approach to maintain access development in squeezing ground identified during the feasibility study. Much is written about squeezing ground, but mainly about how to solve a problem that has already occurred (Potvin \& Hadjigeorgiou 2008; Sandy et al. 2007). The aim of this paper is to give guidance for planning and management solutions for a deposit that will likely encounter squeezing ground conditions. The paper will also discuss operational requirements that need to be considered at the pre-production stage.
\end{abstract}

The paper reviews ground control schemes aimed at controlling movement before and during stoping. It is based on experiences and research conducted at mines experiencing squeezing ground conditions and reviews considerations in design and monitoring to mitigate outcomes associated with squeezing rock masses.

\section{Introduction}

Squeezing ground is a significant problem for many mines that have weak rock mass strength in relation to the induced stress field. Often the conditions leading to squeezing ground are not recognised or underestimated at the feasibility and feasibility stages, leading to significant difficulties in mining the deposit, higher costs and lost resources. The aim of this paper is to discuss problems that cause squeezing, allowing for more informed feasibility study documentation, and make mines to be better prepared for squeezing ground conditions. This paper explores the requirements at the feasibility study level, with examples of the type of ground that needs to be managed.

It is important to understand the impacts of squeezing ground on operations; for example, there will be a need for rehabilitation, hence equipment, time, materials and costs need to be applied to budgets and schedules at the feasibility stage. Data can be collected from diamond drilling that will allow the identification of conditions that lead to squeezing ground. Numerical models can simulate the rock mass response to excavation and, hence, expected deformation limits. As the mine is developed, the database of ground conditions should be updated with feedback into the ongoing design.

\section{$2 \quad$ Defining squeezing ground}

A number of definitions of squeezing ground are available. Potvin and Hadjigeorgiou (2008) listed a number of definitions as part of the Australian Centre for Geomechanics Squeezing Ground Task Force. Several of these are shown in Section 2.1. Section 2.2 describes how to recognise rock mass conditions that may lead to squeezing ground. 


\subsection{Definition of squeezing ground}

A working definition of squeezing rock has been provided by the International Society for Rock Mechanics (ISRM): "Squeezing of rock is the time dependent large deformation which occurs around the tunnel and is essentially associated with creep caused by exceeding a limiting shear stress. Deformation may terminate during construction or continue over a long time period" Barla (1995).

"A practical definition for squeezing ground conditions is when the total displacement of an excavation or, more specifically, the drive closure reaches at least tens of centimetres within the life expectancy of a supported drive. In general, mine oredrives are designed to be in operation up to two years. It is also implied that in squeezing ground conditions the resulting loads and displacements will be greater than the capacity of the support scheme. This often results in the significant failure of ground support scheme and necessitates extensive rehabilitation work" (Potvin \& Hadjigeorgiou 2008).

Potvin and Hadjigeorgiou (2008) summarised other authors' definitions for squeezing ground in five classes (Table 1). This represents squeezing in terms of strain, and squeezing index (SI).

Aydan et al. (1993) use the ratio of peak tangential strain at the circumference of the tunnel $\left(\varepsilon_{\theta}^{a}\right)$ to elastic strain $\left(\varepsilon_{\theta}^{e}\right)$ to define various degrees of squeezing.

Singh et al. (2007) suggest that there is in fact a critical strain beyond which squeezing problems may be encountered during construction. This was defined as the tangential strain level at a point on the opening periphery. Rather than setting this strain as $1 \%$, based on current experience, they suggest that this can be calculated based on the oriented intact rock properties and the in situ modulus of deformation. This approach can then lead to a SI defined as:

$$
S I=\frac{\text { observed or expected strain }}{\text { Critical strain }}=\frac{u_{r} / a}{\varepsilon_{c r}}
$$

where:

$\mathrm{u}_{\mathrm{r}} \quad=$ radial closure and $\mathrm{a}$ is the radius of the opening.

Table 1 Classification for squeezing potential in tunnels, after Potvin and Hadjigeorgiou (2008)

\begin{tabular}{|c|c|c|c|c|c|c|}
\hline \multirow[t]{2}{*}{ Class \# } & \multicolumn{2}{|c|}{ Hoek (2001) } & \multicolumn{2}{|c|}{ Aydan et al. (1993) } & \multicolumn{2}{|c|}{ Singh et al. (2007) } \\
\hline & $\begin{array}{c}\text { Squeezing } \\
\text { level }\end{array}$ & Tunnel strain & $\begin{array}{c}\text { Squeezing } \\
\text { level }\end{array}$ & Tunnel strain & $\begin{array}{c}\text { Squeezing } \\
\text { level }\end{array}$ & SI \\
\hline 1 & $\begin{array}{c}\text { Few support } \\
\text { problems }\end{array}$ & $\varepsilon_{t}<1 \%$ & $\begin{array}{c}\text { No } \\
\text { squeezing }\end{array}$ & $\varepsilon_{\theta}^{a} / \varepsilon_{\theta}^{e} \leq 1$ & $\begin{array}{c}\text { No } \\
\text { squeezing }\end{array}$ & $S I<1.0$ \\
\hline 2 & $\begin{array}{c}\text { Minor } \\
\text { squeezing } \\
\text { problems }\end{array}$ & $1 \%<\varepsilon_{t}<2.5 \%$ & $\begin{array}{l}\text { Light } \\
\text { squeezing }\end{array}$ & $1 \leq \varepsilon_{\theta}^{a} / \varepsilon_{\theta}^{e} \leq 2.0$ & $\begin{array}{l}\text { Light } \\
\text { squeezing }\end{array}$ & $1.0<S I \leq 2.0$ \\
\hline 3 & $\begin{array}{l}\text { Severe } \\
\text { squeezing } \\
\text { problem }\end{array}$ & $2.5 \%<\varepsilon_{t}<5 \%$ & $\begin{array}{c}\text { Fair } \\
\text { squeezing }\end{array}$ & $2.0 \leq \varepsilon_{\theta}^{a} / \varepsilon_{\theta}^{e} \leq 3.0$ & $\begin{array}{c}\text { Fair } \\
\text { squeezing }\end{array}$ & $2.0<S I \leq 3.0$ \\
\hline 4 & $\begin{array}{l}\text { Very severe } \\
\text { squeezing } \\
\text { problem }\end{array}$ & $5 \%<\varepsilon_{t}<10 \%$ & $\begin{array}{c}\text { Heavy } \\
\text { squeezing }\end{array}$ & $3.0 \leq \varepsilon_{\theta}^{a} / \varepsilon_{\theta}^{e} \leq 5.0$ & $\begin{array}{c}\text { Heavy } \\
\text { squeezing }\end{array}$ & $3.0<S I \leq 5.0$ \\
\hline 5 & $\begin{array}{l}\text { Extreme } \\
\text { squeezing } \\
\text { problem }\end{array}$ & $\varepsilon_{t}>10 \%$ & $\begin{array}{c}\text { Very heavy } \\
\text { squeezing }\end{array}$ & $\varepsilon_{\theta}^{a} / \varepsilon_{\theta}^{e}>5.0$ & $\begin{array}{c}\text { Very } \\
\text { heavy } \\
\text { squeezing }\end{array}$ & $5.0<S I$ \\
\hline
\end{tabular}


Table 2 represents squeezing ground as closure and damage description. Closure represents closure between two walls. Damage description is based on observations from underground ground reaction over time.

Table 2 Descriptive classification of squeezing ground

\begin{tabular}{|c|c|c|c|}
\hline \# Class & Squeezing level & Closure (mm) & Damage description \\
\hline 1 & No squeezing & $0-50$ & $\begin{array}{l}\text { No damage to scats behind the mesh. Minor rehab } \\
\text { required. Low capacity ground support schemes sufficient. }\end{array}$ \\
\hline 2 & Light squeezing & $50-100$ & $\begin{array}{l}\text { Minor spalling and scat build up behind mesh. Low } \\
\text { capacity ground support scheme struggles, reinforcement } \\
\text { system with up to } 100 \mathrm{~mm} \text { displacement required. At least } \\
\text { one pass of rehabilitation is likely. }\end{array}$ \\
\hline 3 & $\begin{array}{l}\text { Fair (moderate) } \\
\text { squeezing }\end{array}$ & $100-200$ & $\begin{array}{l}\text { Spalling of walls where ground support is not installed, } \\
\text { with } 0.5 \text { to } 1 \mathrm{~m} \text { depth of failure common, shoulder } \\
\text { bagging, minor floor heave and increased depth of failure } \\
\text { in backs. Low capacity ground support scheme is not } \\
\text { sufficient, a support scheme with } 100 \mathrm{~mm} \text { displacement or } \\
\text { greater is required, cable bolts greatly improve conditions. } \\
\text { Rehabilitation will be common practice. }\end{array}$ \\
\hline 4 & $\begin{array}{l}\text { Heavy } \\
\text { squeezing }\end{array}$ & $200-300$ & $\begin{array}{l}\text { As above, but more extreme, depth of failure } 1.5 \mathrm{~m} \text {. Need } \\
\text { the best dynamically capable support elements, cable bolts } \\
\text { necessary, fibrecrete should be considered to give extra } \\
\text { confinement. Rehabilitation common practice and is } \\
\text { difficult. }\end{array}$ \\
\hline 5 & $\begin{array}{l}\text { Very heavy } \\
\text { squeezing }\end{array}$ & $>300$ & $\begin{array}{l}\text { Practically and economically very difficult to support, } \\
\text { especially for long oredrive development. Crosscutting } \\
\text { faults and high support costs may be acceptable. Consider } \\
\text { mine design/strategy change where possible. }\end{array}$ \\
\hline
\end{tabular}

Figures 1 to 5 show examples of squeezing ground at the different level of squeezing from Table 2. 


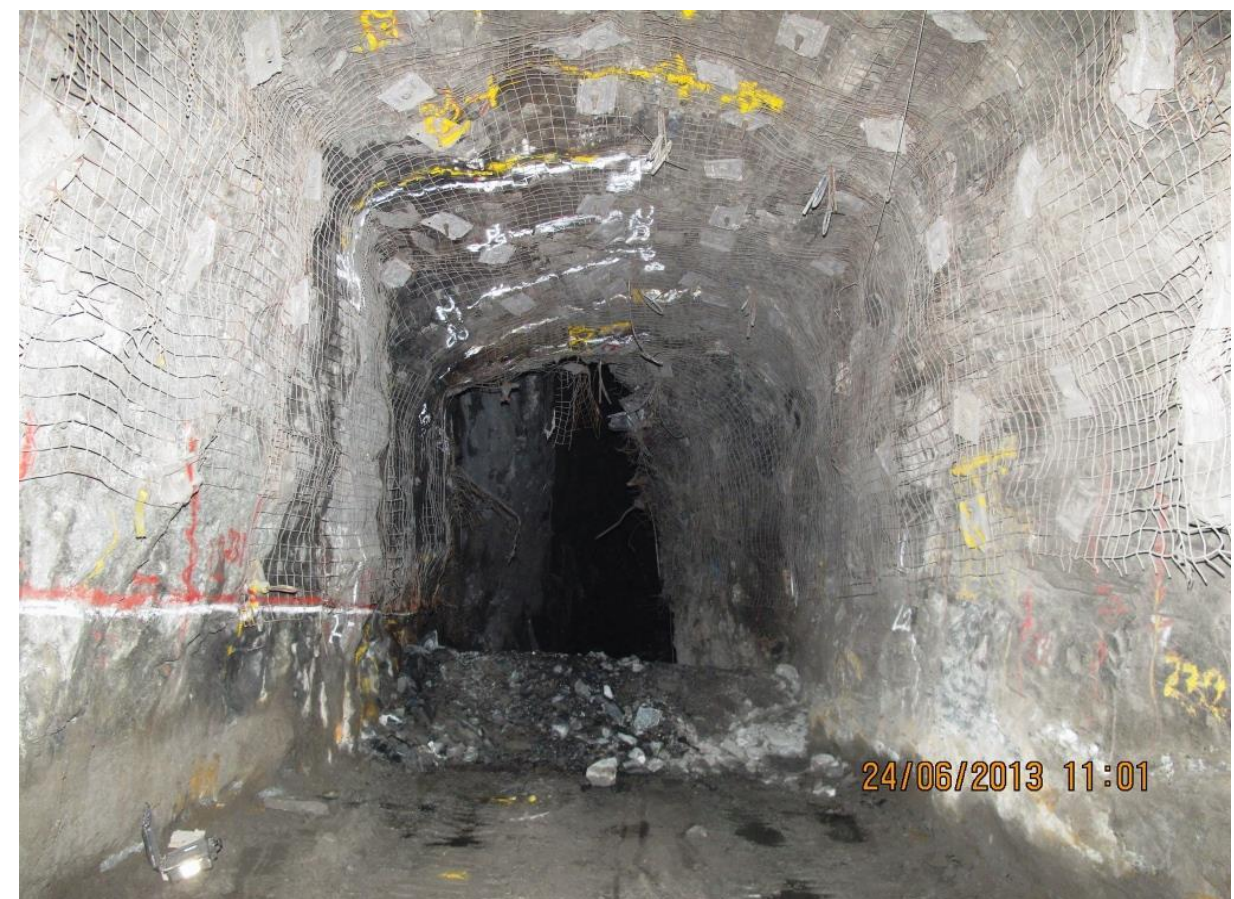

Figure 1 No squeezing - ground conditions resemble a low stress environment where mesh and friction bolts are sufficient to control scats and small wedges often related to blast damage

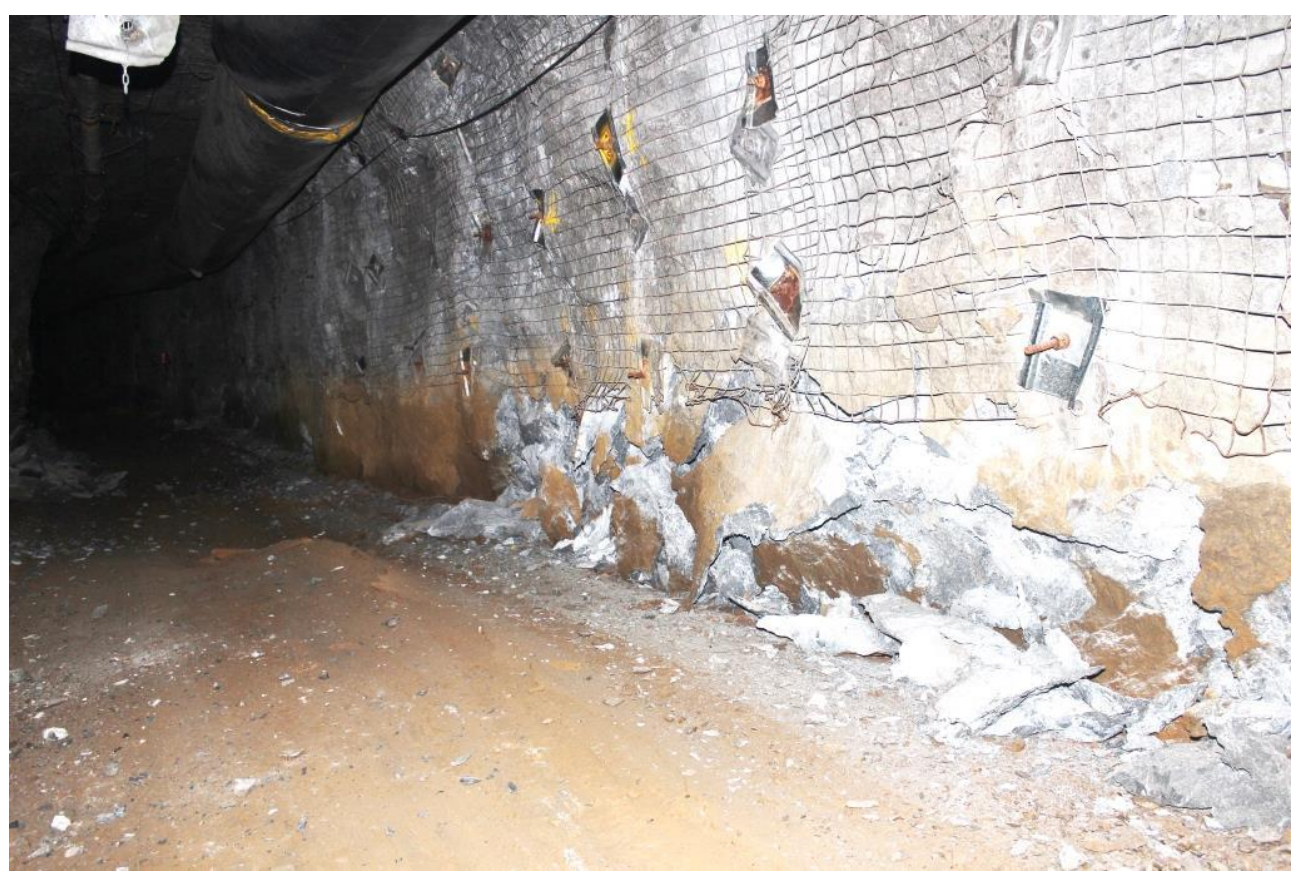

Figure 2 Light squeezing - minor failure/buckling below grade line where there is no support. Scat build-up behind mesh is adequately supported. Reinforcement system is advisable to be increased from friction bolts to a higher capacity bolt 

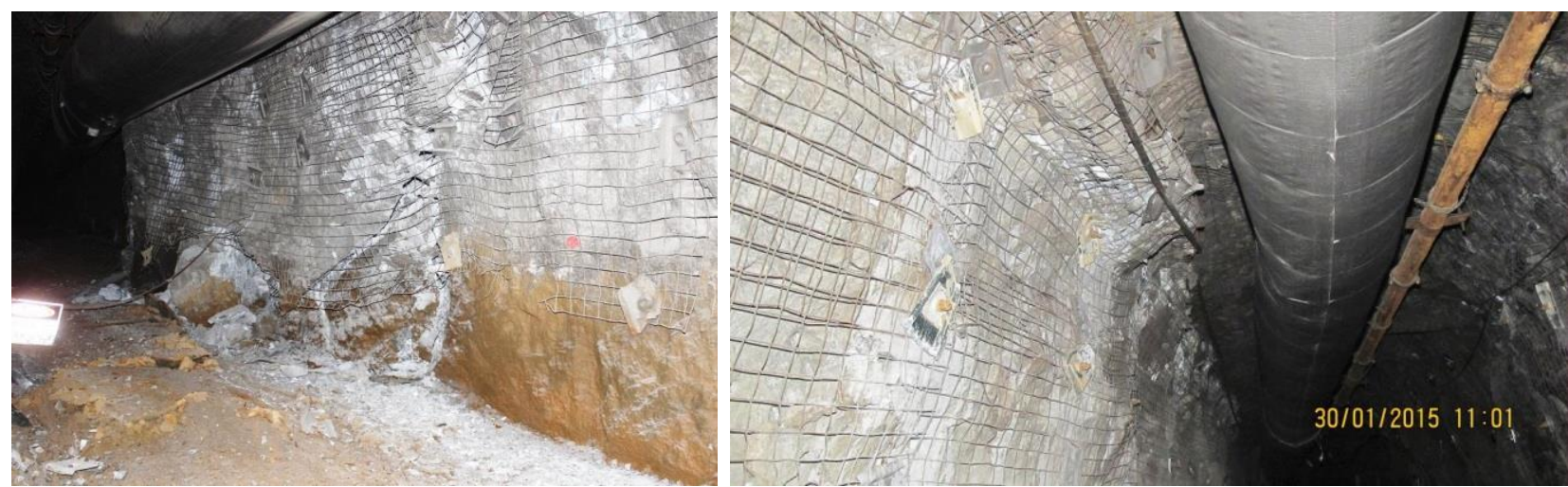

Figure 3 Fair squeezing - intact rock fracturing, increased failure behind mesh, bolts failing, shoulder deformation

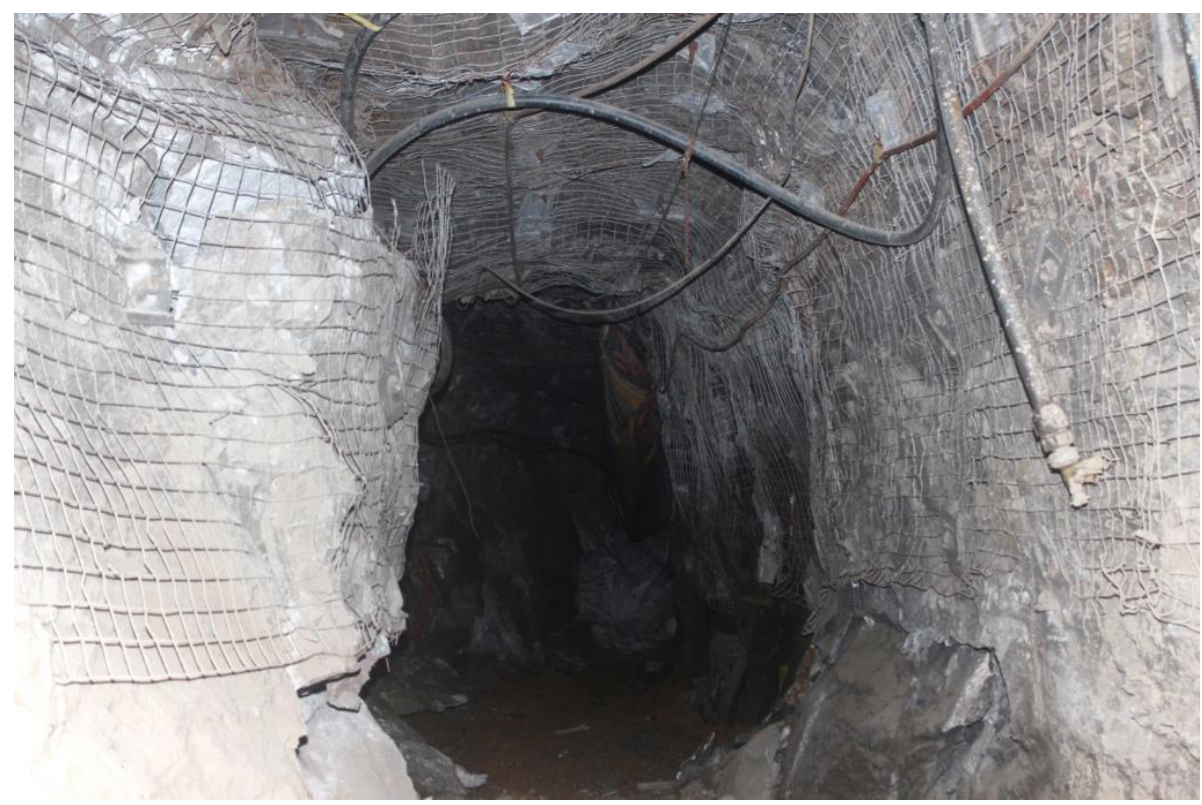

Figure 4 Heavy squeezing - wall movement starts to impact machinery using the drive, increased support failure, depth of failure 1-1.5 m
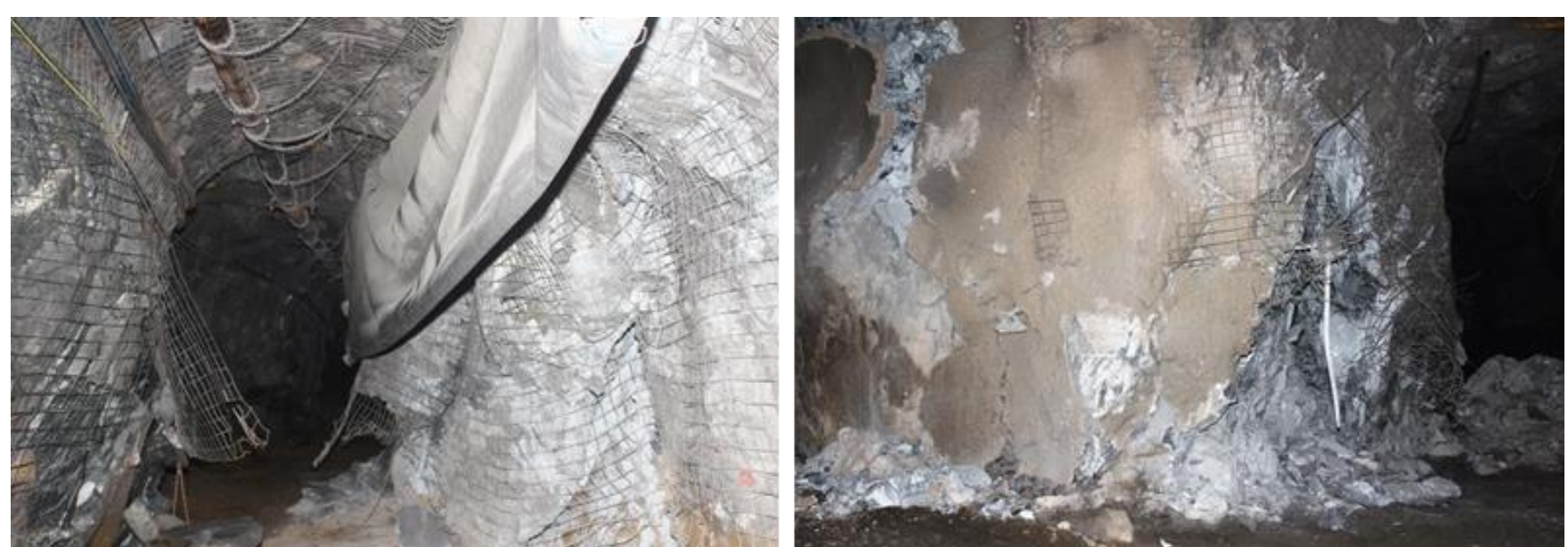

Figure 5 Very heavy squeezing - deformation greater than $1 \mathrm{~m}$, depth of failure exceeding $1.5 \mathrm{~m}$, total wall failure occurring 


\subsection{Recognising squeezing ground potential at the feasibility study stage}

Squeezing ground is usually characterised by several different types of rock types and minerals. In Australia, mines that encounter weak ultramafics are prone to squeezing, for example many of the nickel mines, with Perseverance mine being a well-known example of squeezing ultramafics and shear zones. In Canada, squeezing ground is seen along the Cadillac fault in Rouyn and Val d'Or, which is sometimes associated with the Sudbury igneous complex at depth. In South Africa, squeezing conditions are due mainly to the very high stresses at great depths for the gold and platinum mines, but at significantly shallower depths in the kimberlite dyke block caving diamond mines.

Data collection and analysis is a critical stage in mine design. Data collection starts at the scoping study stage and continues through to the feasibility study. It is critical that capital expenditure must reflect the complexity of the geology and expected geotechnical conditions, allowing for collecting a sufficient quantity of data to represent the size and complexity of the deposit. All too often companies test the bare minimum to reduce expenditure; however, cost saving may lead to incorrect ground characteristics determination, leading to early mine failure or closure. The quantity of data collection and processing needs to be linked to risk of the mining operation.

\subsubsection{Indicators of potential for squeezing ground}

There are a number of identifiers early in a project that indicate the potential for squeezing ground conditions. A list of potential indicators is given below:

- Intact uniaxial compressive rock strength is usually in the range of 40-60 MPa (or less).

- Ultramafic rocks (determining the mineralogy is important as different minerals perform differently).

- Mineralogy - e.g. talc, chlorite content, mica, brucite, tochillonite and antigorite - percentage content will determine severity of squeezing/damage.

- Joint infill materials - talc, sericite, chlorite.

- Intense shearing along faults.

- Wide gauge filled joints/faults.

- Presence of swelling clays, for example, kaolinite, illite and montmorillonite.

- Presence of water - water causes clays to swell, it lubricates joints and increases pore pressure.

- Foliation - closely spaced foliation which is near parallel and near vertical to development may experience buckling failure.

\subsubsection{Depth at which squeezing starts to become a problem}

In Australian mines, principle stress gradients have been measured as high as $0.09 \mathrm{MPa} / \mathrm{vertical}$ metre, (and $\mathrm{k}$ ratio of 2 to 3), squeezing will generally start between 300 and $500 \mathrm{~m}$. Table 3 gives comparisons between Australia, Canada and South Africa of $\sigma_{1}$ in relation to depth. The Australian stress gradient is far higher than in many other areas of the world, which indicates that the depth of when squeezing may become a problem is much shallower in Australia compared to other locations.

Table 3 Stress field comparison between countries ( $d=$ depth), after Lee (2001)

\begin{tabular}{lcccc}
\hline Country & $\begin{array}{c}\text { South African } \\
\text { gold mines }\end{array}$ & Canadian Shield & Australia & $\begin{array}{c}\text { Yilgarn Block } \\
\text { (Western Australia) }\end{array}$ \\
\hline$\sigma_{1}(\mathrm{MPa})$ & $0.026 \mathrm{~d}$ & $12+0.0366 \mathrm{~d}$ & $0.057 \mathrm{~d}$ & $0.094 \mathrm{~d}$ \\
\hline
\end{tabular}


Examples of how depth will affect different rock types are shown below. Geological structures and alteration may result in different degrees of squeezing for the same rock at different depths (refer to Table 2):

- Basalts: fresh $\approx 700 \mathrm{~m}$; altered $\approx 350 \mathrm{~m}$.

- Dolerites: fresh $\approx 750 \mathrm{~m}$; altered $\approx 550 \mathrm{~m}$.

- Felsic/mafic sediments: fresh $=350-450 \mathrm{~m}$; altered $=400-500 \mathrm{~m}$; very variable

- Serpentinised talc-carbonates $=\mathbf{2 0 0} \mathrm{m}$; i.e. at very shallow depths

- Porphyries $=750 \mathrm{~m}$; some are prone to strain bursting at much shallower depths.

- Proterozoic dolerite dykes $=500 \mathrm{~m}$.

This type of information is vital at the feasibility stage. Much of this information is available for many regions around the world where experiences have been recorded and can be passed on to new projects.

\subsubsection{Identifying squeezing rock at feasibility stage}

If any of the indicators for potential squeezing ground have been identified through a combination of core logging, rock testing or depth of mining for the region, the feasibility study should make allowances for potential reduction in extraction ratio, reduction in mining rate and multiple pass rehabilitation, which are covered in Section 3.

\section{$3 \quad$ Mine design for squeezing susceptible ground}

The most effective way to manage a mine with squeezing ground conditions is to account for the squeezing rock mass at the feasibility stage and use the design to minimise and control squeezing ground conditions. This involves a good understanding of the geomechanical properties of the rock mass. This is determined through data collection, rock mass model assumptions and modelling. Where design is inadequate, this will lead to production problems later in the mine life, this is well documented in Beck and Duplancic (2005).

\subsection{Considerations for mine design in squeezing rock}

This section details aspects of a mine design that need to be considered in order to reduce the risk of squeezing. When improper designs are implemented, the impact to production is significant, leading to costly delays with impact on cash flow and potentially loss of reserves.

\subsubsection{Level spacing}

A suitable pillar between levels is required to reduce interaction and limit early pillar failure. The design needs to aim for the maximum level spacing possible. In narrow vein operations, there is a tendancy to have close level spacing, as often small equipment is used that may have limited longhole drilling capability or due to orebody geometry or complexity. Mines with less than $15 \mathrm{~m}$ spacing between floor and backs have a far greater risk of rock mass failure than if greater than $15 \mathrm{~m}$.

\subsubsection{Drive lengths}

In orebodies that consist of long narrow veins, the ability to manage and maintain access for extended periods of time is a significant problem, given the induced stress field from mining. This often leads to multiple passes of rehabilitation that become costly, which in turn threatens the economic viability of the project. Long orebody drives result in the significant problem of keeping the drive open for the life of the level. Consideration needs to be given to breaking the level into multiple mining fronts, with multiple accessways, and potential access pillars or regional pillars. 


\subsubsection{Access and central pillars}

A central access to long orebodies is often justified on an economic sense as it allows more working areas in ore for less capital development. In practice, it is important to understand how the rock mass conditions in the central access will change with extraction and impact the longer term stability of the mine. Working back towards a central pillar, at depth, results in significant stress changes allowing unfavourable ground conditions to exist. Often a large pillar will need to be left around the access, which sterilises a large amount of ore. If this decision is made during the operational life of the mine then this results in a significant revenue loss. If planned at the feasibility stage the access pillar could become a regional pillar and can be strategically placed and a reserve figure more accurately determined. The induced stress which impacts on mine infrastructure can also be evaluated.

Long orebodies result is significant rock mass response with increase in stress on remaining rock. Regional pillars are an effective way of managing stress redistribution around working areas, enabling extraction to take place.

\subsubsection{Optimising drive dimensions}

Drive dimensions and profile are often selected on the largest piece of machinery that will be required to fit in that profile. It is important to consider that small drive dimensions often result in reinforcement elements being inadequately installed (angle and depth) due to long jumbo booms. Equipment must be fit for purpose. Selection of larger development and equipment may also require greater initial ground support scheme expenditure but may well save additional costs, time and production from reduced rehabilitation requirements.

\subsubsection{Optimising drive profile}

Arched profiles are inherently more stable than a square profile. Consideration on the extent of the arch is important, from a semi arch to full arch to near circular profile. Consideration of controlling structure may dictate that a shanty profile is most suitable.

\subsubsection{Regional pillars}

Consideration to pillar placement is needed at the feasibility stage. Pillars can help reduce the extent of rock mass damage in the remaining areas and hence increase the probability of ore recovery. It may not always be possible to mine the entire orebody. Realisation of a reduced realistic recovery is important at the feasibility study stage so reserves that can never be mined (either practically or economically) should not be included in the reserves estimation. Pillars may take the form of large regional pillars, strategically placed pillars to split mining fronts, central access pillars and checker-board sill pillars.

\subsubsection{Sequencing}

Sequence is critical to controlling squeezing. Ground support schemes can be considered as secondary means to control squeezing, where sequence is the primary method. Squeezing in many cases cannot be stopped or controlled by ground support schemes, whereas an appropriate mining sequence and mine design improve the global stability of a mine. Numerical modelling can determine an optimal mining front to an acceptable damage potential to the installed ground support scheme and company risk profile. When developing a sequence it is important to determine factors that affect stability, productivity and safety. Stoping lead/lag angle along with length of the stoping front are critical to determine and control squeezing ground. The incorrect angle will result in significant induced stress being created on the stopes and accesses.

\subsubsection{Rate of development and timing of ground support scheme placement}

The rate at which development should occur is important. Some sites allow horizontal ore development to get well ahead of the stoping sequence as a means of meeting ore tonnes target. The subsequent long drive 
life may result in ground support schemes which are not capable of coping with the stress changes induced by stoping. The vertical rate of advance will result in changing stress and strain environments. The high stress gradient in the Yilgarn Craton of Western Australia results in a very rapid change of induced stress and strain during stoping. Thus changing rock mass conditions will occur over a shorter time period in sublevels developed in advance of the mining front. The planning stage needs to account for the rate of change in induced stress allowing timely changes to ground support scheme and, in some cases, mining method. The incorrect ground support scheme installed too early in many levels of development may result in:

- Failure of the ground support scheme in the future induced stress environment.

- Displacement capacity is used up or exceeded before stoping starts and significant rehabilitation is required.

- Corrosion occurring due to time elapsed between installation and stoping.

- Inability to change mine design, level spacing, orientation etc. due to the committed development.

- Making use of developing into already yielded ground, resulting in a less severe stress path.

\subsubsection{Design factors for calculations}

When using rock mass characterisation methodologies, ensure that the relevant factors are used. For example, when using the Q-system, note the stress reduction factor (SRF) values for squeezing ground (Norwegian Geotechnical Institute 2013) need to be the most up-to-date reference. Table 4 shows the 2013 Q-system parameters for squeezing rock mass.

Table 4 SRF parameters and descriptions from Q-system Handbook (Norwegian Geotechnical Institute 2013)

\begin{tabular}{l|c|c|}
\hline c) $\begin{array}{l}\text { Squeezing rock: plastic deformation in incompetent rock under the influence of } \\
\text { high pressure }\end{array}$ & $\sigma_{\mathrm{e}} / \sigma_{\mathrm{c}}$ & SRF \\
\hline M Mind squeezing rock pressure & $1-5$ & $5-10$ \\
\hline N Heavy squeezing rock pressure & $>5$ & $10-20$ \\
\hline d) Swelling rock: chemical swelling activity depending on the presence of water & SRF \\
\hline O Mild swelling rock pressure & $5-10$ \\
\hline P Heavy swelling rock pressure & $10-15$ \\
\hline
\end{tabular}

Note: iv) Determination of squeezing rock conditions must be made according to relevant literature (i.e. Singh et al. 1992; Bhasin \& Grimstad 1996)

Note Table 1 references the later work by Singh et al. 2007, while the Q-system references an earlier work from Singh when describing squeezing rock mass conditions.

\subsubsection{Rehabilitation rules}

Rules or guidelines need to be developed for when to start rehabilitation, which are based on recorded ground displacement, yield capability of ground support scheme, percent of failed components of the ground support scheme and closure resulting in minimum drive width based on equipment width requirements.

\subsection{Modelling}

Most numerical modelling is conducted when mines have already started to encounter ground control issues. This is mainly due to having actual data to be able to calibrate models, but may also be due to a lack 
of identification and interpretation of early warning signs, or understanding of the problem. Numerical modelling is not popular at the feasibility study phase, but the modelling industry now has enough data and examples that can be applied to feasibility study models. Beck et al. (2013) propose a representative elementary volume (REV) properties scheme for strain softening, and dilatant (SSD) models, comprising of empirical relationships for REV properties, as a function of common pre-mining data. The aim is to cater for mines where no calibration is possible to undertake modelling with some degree of confidence.

Modelling at the feasibility stage will allow a far better understanding of future requirements. The precision of the model will be impacted by the quantity and resolution of the available data, but would be able to give a bracket around the expected depth that squeezing may occur and indication as to what extent deformation is expected. This allows the required changes to mine design and/or sequence as discussed in Section 3.1 to be planned and implemented before Class 3 squeezing starts (Table 2). The key requirement in planning is that actual most likely performance should be evaluated, rather than blind assumptions that any problem will be manageable with a minor change or ground support scheme improvements (Beck \& Duplancic 2005).

If modelling has been undertaken either at feasibility stage or during operations, the mine will have an indication of when squeezing is expected and can target data collection and monitoring to pick up the onset of squeezing (transition from level 1 to level 2 ) and assist in future model calibration and mine planning. By using periodic review and update of modelling, it gives the mine the maximum time and chance of identifying potential issues and collect the required information.

Calibration is the best process for forecasting the behaviour of excavations or rock, so it is therefore critical that the correct resolution of data is gathered. Beck et al. (2013) provide an initial guide for representing structures in a discontinuum model. If the purpose of the model is to estimate behaviour at a certain length scale, how must discontinuities of each length scale range be represented?

\subsection{Design process}

Figure 6 shows a flow chart of a design process to follow when designing for squeezing conditions. Modelling forms a large proportion of the design process. Modelling based on experience of similar ground conditions is an effective means to initially design a mine so as to select the most appropriate mining sequence, ground support schemes and management systems. 


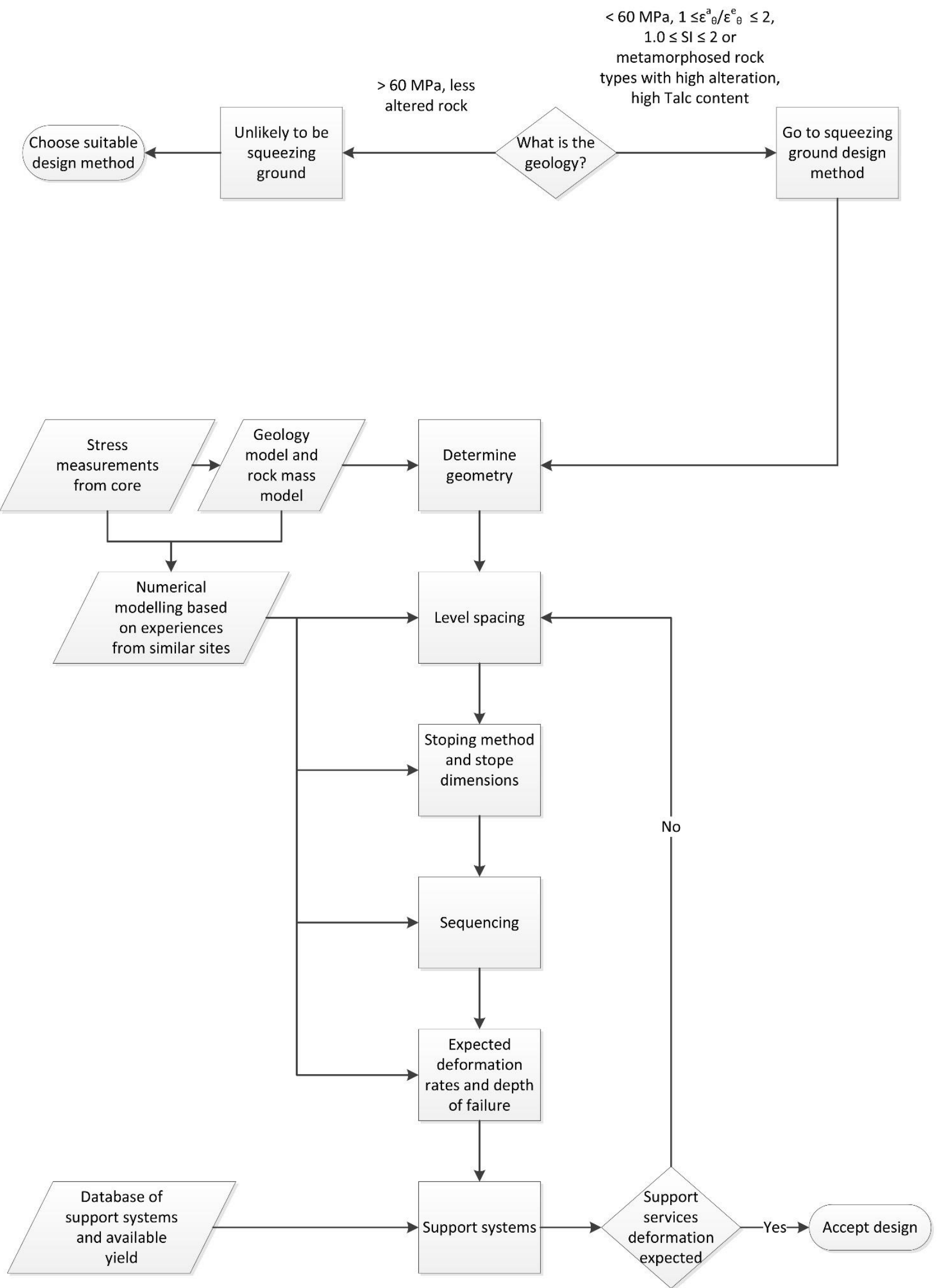

Figure 6 Design methodology for squeezing ground 


\section{$4 \quad$ Ground support schemes}

Ground support schemes on many mines evolve as mining/extraction proceeds and problems are encountered. This may lead to additional expenses, due to production delays and testing scheme response to evaluate what works. Understanding how the ground will behave through modelling will allow improved support system selection early on in the mine life. Installation of the appropriate ground support systems early in the opening of development will allow improved control of the rock mass. Table 5 is a non-exhaustive summary of reinforcement systems and support elements, their capabilities, disadvantages and examples of types of products on the market.

Table 5 Ground support components, *not tested to failure

\begin{tabular}{|c|c|c|c|c|c|}
\hline Bolt type & $\begin{array}{l}\text { Capacity } \\
\left(\mathrm{kN} / \mathrm{m}^{2}\right)\end{array}$ & $\begin{array}{l}\text { Yield } \\
(\mathrm{mm})\end{array}$ & Advantages & Disadvantages & Examples/suppliers \\
\hline $\begin{array}{l}\text { Friction bolt } \\
\text { (45-47 } \mathrm{mm} \\
\text { diameter) }\end{array}$ & $25-40$ & 100 & $\begin{array}{l}\text { Cheap, pinning mesh } \\
\text { up, rehab }\end{array}$ & $\begin{array}{l}\text { Low yield, shearing, } \\
\text { corrosion }\end{array}$ & $\begin{array}{l}\text { Common to all support } \\
\text { suppliers: Villaescusa et } \\
\text { al. (2010) }\end{array}$ \\
\hline $\begin{array}{l}\text { Pumpable } \\
\text { bolts } \\
\text { (3-3.2 } \mathrm{mm} \text { wall } \\
\text { thickness) }\end{array}$ & $100-120$ & 300 & $\begin{array}{l}\text { Increased yield, can } \\
\text { install in broken } \\
\text { ground - good for } \\
\text { rehab }\end{array}$ & $\begin{array}{l}\text { Corrosion potential } \\
\text { when not coated, } \\
\text { poor shear resistance } \\
\text { and expensive }\end{array}$ & $\begin{array}{l}\text { Swellex, Omega, } \\
\text { Python: ground support } \\
\text { catalogues Jennmar, } \\
\text { DSI, Minova }\end{array}$ \\
\hline $\begin{array}{l}\text { Threadbar } \\
\text { (20-26 mm } \\
\text { diameter) }\end{array}$ & $220-300$ & $20-120$ & $\begin{array}{l}\text { High static capacity, } \\
\text { when debonded or } \\
\text { partially debonded } \\
\text { the yieldability } \\
\text { increases, good for } \\
\text { minor squeezing }\end{array}$ & $\begin{array}{l}\text { Low yield capacity } \\
\text { when not decoupled, } \\
\text { installation with resin } \\
\text { encapsulation difficult } \\
\text { in broken ground }\end{array}$ & $\begin{array}{l}\text { Gewie bolt, Secura bolt, } \\
\text { JTech Ground support } \\
\text { catalogues Jennmar, } \\
\text { DSI, Minova }\end{array}$ \\
\hline Yielding bolts & $120-300$ & $200-500$ & $\begin{array}{l}\text { Specially designed to } \\
\text { yield, some bolts } \\
\text { responded better to } \\
\text { slow deformation } \\
\text { than others }\end{array}$ & $\begin{array}{l}\text { Cost, difficulty in } \\
\text { broken ground }\end{array}$ & $\begin{array}{l}\text { Garford yielding bolt, } \\
\text { D bolt, Yield-Lok, } \\
\text { cone bolt: } \\
\text { Varden et al. (2008); } \\
\text { Zhou and Zhao (2011) }\end{array}$ \\
\hline Hybrid bolts & $100-300$ & $\begin{array}{l}>100, \\
\text { upper } \\
\text { limit not } \\
\text { proven }\end{array}$ & $\begin{array}{l}\text { One pass system, can } \\
\text { install in broken } \\
\text { ground, end anchored }\end{array}$ & $\begin{array}{l}\text { High capacity, but } \\
\text { stiff, expensive, new } \\
\text { to the market and } \\
\text { needs time to prove }\end{array}$ & $\begin{array}{l}\text { Sandvic MD bolt, DSI } \\
\text { KinLok, Jennmar Mech } \\
\text { Lok: ground support } \\
\text { catalogues Jennmar, } \\
\text { DSI, Minova }\end{array}$ \\
\hline $\begin{array}{l}\text { Plain stand } \\
\text { cables }\end{array}$ & 250 & $100-150$ & $\begin{array}{l}\text { Large spans and } \\
\text { increase capacity in } \\
\text { walls }\end{array}$ & - & $\begin{array}{l}\text { Most ground support } \\
\text { suppliers, ground } \\
\text { support catalogues } \\
\text { Jennmar, DSI, Minova }\end{array}$ \\
\hline Yielding cables & $120-250$ & 300 & $\begin{array}{l}\text { Large spans and } \\
\text { increase capacity in } \\
\text { walls - greater than } \\
\text { plain strand cables }\end{array}$ & - & $\begin{array}{l}\text { Ground support } \\
\text { catalogue - Garford }\end{array}$ \\
\hline $\begin{array}{l}5.6 \mathrm{~mm} \text { weld } \\
\text { mesh }\end{array}$ & 9.2 & 250 & - & - & $\begin{array}{l}\text { Ground support } \\
\text { catalogues Jennmar, } \\
\text { DSI, Minova }\end{array}$ \\
\hline $\begin{array}{l}10 \mathrm{~mm} \text { woven } \\
\text { mesh* }\end{array}$ & 115 & 600 & $\begin{array}{l}\text { High static and yield } \\
\text { capacity, flexible }\end{array}$ & Heavy and expensive & Jennmar \\
\hline
\end{tabular}




\begin{tabular}{|c|c|c|c|c|c|}
\hline Bolt type & $\begin{array}{l}\text { Capacity } \\
\left(\mathrm{kN} / \mathrm{m}^{2}\right)\end{array}$ & $\begin{array}{l}\text { Yield } \\
(\mathrm{mm})\end{array}$ & Advantages & Disadvantages & Examples/suppliers \\
\hline Tecco mesh & 190 & 350 & $\begin{array}{l}\text { High strength, high } \\
\text { deformability }\end{array}$ & $\begin{array}{l}\text { Needs special } \\
\text { equipment to install, } \\
\text { cost }\end{array}$ & Geobrugg \\
\hline Osro straps & - & - & $\begin{array}{l}\text { High static and yield } \\
\text { capacity, flexible }\end{array}$ & - & $\begin{array}{l}\text { Ground support } \\
\text { catalogues Jennmar, } \\
\text { DSI, Minova }\end{array}$ \\
\hline
\end{tabular}

\subsection{Consideration in ground support schemes}

In scheme design, a number of considerations need to be considered for the different levels of ground reaction.

\subsubsection{Design considerations}

- With an increase in deformation, increasing the bolt density has improved control of deformation as the reinforcement systems typically have greater resistive capacity than the support elements. Where bolt spacing is wide $(>1.5 \times>1.5 \mathrm{~m})$ the ground tends to deform around the bolts with bolt heads pulling through the surface plates or through the support element. With closely spaced bolting the rock mass tends to transfer load to the bolts promoting the element to do work to control ground displacement. Bolt densities commonly used vary from, $1.1 \times 1.2 \mathrm{~m}$ to $0.9 \times 0.9 \mathrm{~m}$.

- Depth of embedment is a critical factor of controlling the rock mass. It is important to install the longest support element possible with consideration to angle of installation and type of equipment used in comparison to drive size.

- Full coverage of the drive profile is a necessity. It is common practice in Australian mines to install bolts and surface support to gradeline. This results in the lower walls being unsupported and this is where the greatest movement often occurs. Not providing full coverage to the lower walls allows the rock mass failure to undercut and propagation up the wall behind the installed scheme.

- Surface support is critical to rock mass confinement and retention between the bolts. The two most common systems used are fibrecrete and wire mesh. Australian mines often tend to use more fibrecrete, whereas Canadian mines use mesh (screen) as the primary surface support (Potvin \& Hadjigeorgiou 2008). Fibrecrete alone is effective in low squeezing conditions, but tends to fail under tension after a small amount of movement. Although fibrecrete increases the amount of confinement slowing the onset of movement, in extreme squeezing conditions fibrecrete becomes more partial to breaking, becoming a hazard. Mesh embedded in fibrecrete is considered by some to be an effective control, but observations show that in extreme squeezing the mesh will snap. Mesh by itself or over the fibrecrete (to contain the broken slabs) is the most common form of surface support system in Australia. Using mesh over fibrecrete allows for the early confinement provided by the fibrecrete; then, as it breaks up, the mesh contains the large slabs. Weld mesh is the most commonly used form of mesh, but has the tendency of breaking at the welds. Woven or chainlink mesh is considered most effective in dealing with large deformation, with a number of products on the market. Geobrugg's Teco mesh, a flexible chainlink mesh, is the most effective at containing large amounts of movement (including rockbursts), due to its flexibility and high strength. A recent development is a $10 \mathrm{~mm}$ woven mesh, now being used in several Australian mines with the aim of providing containment of very heavy squeezing conditions.

- $300 \mathrm{~mm}$ wide Osro or mesh straps are useful in increasing the capacity of the ground support scheme by more effectively linking the individual components together. These can be installed across the drive profile or along the drive dependent on local geology. Pillars are exposed to 
increased surface area and increased risk of squeezing and are greatly benefiting from strapping. Straps are recommended to be installed with cable bolts allowing deeper retention.

- Cable bolts have been used and are necessary in fair to very heavy squeezing categories Classes 4 and 5. Cables allow embedment beyond the capabilities of solid bar installation. Cables have a higher shear capacity than solid bars and allow increased movement without failing the individual components. Common cable bolt pattern is $2 \times 2 \mathrm{~m}$, but has been brought down to $1 \times 1 \mathrm{~m}$ in very heavy squeezing.

- Yielding bolt development and availability in the market has significantly increased in recent years, mainly targeting seismically active mines, but can equally be considered for squeezing ground conditions. These bolts have capacity between 200 and $300 \mathrm{~mm}$ and should be considered as primary reinforcement for Class 3 squeezing condition onwards. An important consideration is the shearing on yielding bolts reducing their ability to elongate resulting in early failure.

\section{$5 \quad$ Monitoring}

Monitoring in squeezing rock masses is crucial for good ground control management. Developing a strategy early is important in order to allow the timely installation of equipment and subsequent data collection. There is a large range of monitoring systems available and, with modern communication systems, data can be transmitted to a database for easy analysis. Monitoring systems can be expensive, depending on the mine extent, and it is therefore beneficial to plan for a mine wide system and build this into the budget. Decisions such as communication are important; there will be a need to connect the instruments to the mine's communication system or, perhaps, to the seismic system.

Monitoring should be undertaken to determine the following variables:

- Rate of movement.

- Location of movement.

- Depth of failure.

- Selection of support systems.

- Timing.

- Knowing when to replace reinforcement.

- Knowing where to place pillars.

- Knowing when to abandon an area.

Instrumentation available:

- Tape extensometers: easy to install can give early indications of movement.

- MPBX: allows depth of failure and movement to be determined - this is very important data to collect as it helps to monitor support performance, determines depth of failure.

- Smart cables: monitors performance of cable bolts, determines replacement.

- Laser scanning: high resolution scan - recent developments have developed a hand held scanner, which although it does not have the accuracy of current scanners is quick and cheap, allowing regular surveys.

- Photogrammetry: Both Sirovision and Adamtech provide photogrammetry systems that are able to effectively capture geotechnical, geological and closure data. Photogrammetry is not highly accurate, +/- $50 \mathrm{~mm}$ - dependent on survey accuracy - however, it is good to show where and how movement is occurring and it provides a photographic record. 


\section{Conclusion}

Squeezing ground conditions pose a significant threat to an operation due to significant difficulties in mining a deposit, high costs and lost resources. Early identification of the potential for squeezing ground conditions at the feasibility stage and appropriate mine planning will significantly reduce the risks associated with mining such deposits. Mine planning and scheduling are key to successful ore recovery, as it is not always possible to control squeezing ground with additional ground support.

- Understanding the nature and extent of squeezing ground conditions at the feasibility stage is essential, leading to long term cost savings, ease of management and retention of resources. This includes sufficient data collection to understand the problem and capital investment.

- Modelling is necessary at the feasibility stage, based on drill hole data and related to similar deposits. During the mine life calibrations can be conducted as new data is collected.

- Ground support systems and monitoring systems need to be considered at the feasibility stage.

- Mine development should be undertaken just in time, to reduce the time a drive is required to remain serviceable and the potential number of rehabilitation cycles.

- Identification of the potential for squeezing ground conditions must be translated to operations, allowing monitoring to be implemented at depths where squeezing may initiate. Early identification of squeezing conditions is possible using the information outlined in this paper.

\section{Acknowledgement}

The authors thank the following companies for information and help provided: BHP Billiton Nickel West, Beck Engineering, MMG and Jennmar.

\section{References}

Aydan, Ö, Akagi, T \& Kawamoto, T 1993, 'The squeezing potential of rock around tunnels: theory and prediction', Rock Mechanics and Rock Engineering, vol. 2, pp. 137-163.

Barla, G 1995, 'Squeezing rocks in tunnels', ISRM News Journal, vol. 3, no. 2, pp. 44-49.

Beck, DA \& Duplancic, P 2005, 'Forecasting performance and achieving performance indicators in high stress and seismically active mining environments', in Y Potvin \& M Hudyma (eds), Proceedings of the Sixth International Symposium on Rockburst and Seismicity in Mines (RaSiM6), Australian Centre for Geomechanics, Perth, pp. 409-418.

Beck, DA, Lilley, CR, Reusch, F, Levkovitch, V, Putzar, G \& Flatten, A 2013, 'A preliminary, calibrated scheme for estimating rock mass properties for non-linear, discontinuum models', Proceedings of the 3rd ISRM Symposium on Rock Mechanics (Sinorock 2013), International Society for Rock Mechanics, Lisboa, 6 p.

Bhasin, R \& Grimstad, E 1996, 'The use of stress - strength relationships in the assessment of tunnel stability', Tunneling and Underground Space Technology, vol. 11, no. 1, pp. 93-98.

Hoek, E 2001, 'Big tunnels in bad rock', ASCE Journal of Geotechnical and Geoenvironmental Engineering, vol. 127, no. 9, pp. 726-740.

Lee, M, Pascoe, M \& Mikula, P 2001, Virgin rock stresses vs rock mass strength in Western Australia's Yilgarn greenstones', Proceedings of the WA Ground Control Workshop, Australian Mining Consultants Pty Ltd, Melbourne, $41 \mathrm{p}$.

Norwegian Geotechnical Institute 2013, Using the Q-system handbook: rock mass classification and support design, Norwegian Geotechnical Institute, Oslo.

Potvin, Y \& Hadjigeorgiou, J 2008, 'Ground support strategies to control large deformations in mining excavations, Journal of the Southern African Institute of Mining and Metallurgy, vol. 108, pp. 393-400.

Sandy, M, Gibson, W \& Gaudreau, D, 2007, 'Canadian and Australian Ground Support Practices in High Deformation Environments', in Y Potvin (ed.), Proceedings of the Fourth International Seminar on Deep and High Stress Mining (Deep Mining '07), Australian Centre for Geomechanics, Perth, pp. 297-311.

Singh, B, Jethwa, JL, Dube, AK \& Singh, B 1992, 'Correlation between observed support pressure and rock mass quality', Tunnelling and Underground Space Technology, vol. 7, no. 1, pp. 59-74.

Singh, M, Singh, B \& Choudhari, J 2007, 'Critical strain and squeezing of rock mass in tunnels', Tunnelling and Underground Space Technology, vol. 22, pp. 343-350.

Varden, R, Lachenicht, R, Player, J, Thompson, A \& Villaescusa, E 2008, 'Development and implementation of the Garford dynamic bolt at the Kanowna Belle Mine', Proceedings of the 10th Underground Operators' Conference, The Australasian Institute of Mining and Metallurgy, Melbourne, pp. 95-102. 
Villaescusa, E, Thompson, A, Player, J \& Morton, E 2010, Dynamic testing of ground control systems, MERIWA report, no. 287, Project M349A, Minerals and Energy Research Institute of Western Australia, Perth.

Zhou, Y \& Zhao, J (eds) 2011, Advances in rock dynamics and applications, CRC Press, Boca Raton, FL. 